\title{
Drug repurposing in leukemia treatment and hematopoietic stem cell transplantation
}

\author{
Alexey B. Chukhlovin \\ State I. Pavlov Medical University, St. Petersburg, Russia \\ Professor Dr. Alexey B. Chukhlovin, R.Gorbacheva Memo- \\ rial Research Institute of Children Oncology, Hematology \\ and Transplantation, The First St. Petersburg State I. Pavlov \\ Medical University, L. Tolstoy St 6-8, 197022, St. Petersburg, \\ Russia
}

R.Gorbacheva Memorial Research Institute of Children Oncology, Hematology and Transplantation, The First St. Petersburg

\author{
Phone: +7 (921) 3250094 \\ E-mail: alexei.chukh@mail.ru
}

Citation: Chukhlovin AB. Drug repurposing in leukemia treatment and hematopoietic stem cell transplantation. Cell Ther Transplant 2019; 8(1): 12-19.

\section{Summary}

Over last decade, a number of studies has concerned possible implications of "old" medical drugs, as additional tools for cancer treatment. The main reasons for extension of drug indications are as follows: (1) limited efficiency or high costs of targeted oncogene protein inhibitors or specific monoclonal antibodies for therapy; (2) new molecular targets were revealed for some drugs traditionally used to other therapeutic purposes; and (3) sufficient decline of development costs for the new therapies performed by the "old" drugs. The list of such repurposed drugs now includes dozens of medications commonly used for treatment of cardiovascular diseases, diabetes mellitus, epilepsia, different inflammatory disorders. The present review deals, mainly, repurposing of anti-infectious drugs, including those used in prevention and management of infectious complications occurring in cytostatic therapy of leukemia and lymphomas, e.g., tetracyclines, erythromycin derivatives, as well as fluoroquinolones, antiviral compounds etc.
The antitumor effects were of these candidates for repurposing were demonstrated upon screening of their cytostatic effects in leukemic and other cancer cell lines. Some studies were performed in experimental tumor-bearing animals. Only few clinical trials were carried out in patients with leukemias and lymphomas following hematopoietic stem cell transplantation (HSCT), which showed some positive effects of antibacterial drugs in terms of graft-versus-host disease (GvHD) prevention, or prolonged survival of the patients. Controlled clinical trials of common anti-infectious drugs are required for this repurposing.

\section{Keywords}

Antibacterial drugs, repurposing, anticancer effects, leukemia treatment, hematopoietic stem cell transplantation.

\section{Introduction}

Additional therapeutic effects of "old", drugs for novel clinical indications have been studied over last decades. Novel suggestions for repurposing of different medical drugs for cancer treatment have been made over recent years $[1,2]$.

There are three main reasons for these proposals: (1) limited efficiency of novel inhibitors or specific monoclonal antibodies targeted for oncogene-specific molecules; (2) new molecular targets were revealed for some drugs traditionally used to other therapeutic purposes; and (3) eventual decline of development costs for the new therapies performed by the “old" drugs.

A variety of drugs used in different somatic disorders is now considered as complementary tool for treatment of malignancies. These candidate compounds are listed in several indexes available online, e.g., the Drug Repurposing Portal supported by Excelra [3]. In addition, a number of recent review articles concern different aspects of old drug applications in cancer therapy $[1,4,5]$. 
It should be noted, however, that most cytostatic and anticancer effects of the repurposed drugs are shown in the in vitro models, or in experimental animals, thus suggesting a long way until their clinical implication. The big data collected from drug screening in different models are analyzed by different bioinformatic approaches, e.g. [6], thus accelerating the drug selection process to some degree.
The specific aim of our study was to discuss probable anticancer effects of some anti-infectious drugs which are now widely used in hematopoietic stem cell transplantation protocols.

Some candidate drugs intended for repurposing in cancer treatment are listed in Table 1.

Table 1. Summary of drugs used for treatment of common disorders, their primary indication, non-cancer and cancer targets

\begin{tabular}{|c|c|c|c|c|c|}
\hline Agent & Primary indication & $\begin{array}{l}\text { On-target- } \\
\text { TARGET Primary } \\
\text { effects }\end{array}$ & $\begin{array}{l}\text { On target } \\
\text { antitumor effects }\end{array}$ & $\begin{array}{l}\text { Biological antitumor } \\
\text { effects }\end{array}$ & Reference \\
\hline $\begin{array}{l}\text { CCA } \\
\text { Verapamil } \\
\text { Diltiazem }\end{array}$ & $\begin{array}{l}\text { Anti-arrhytmic L-type } \\
\text { Ca2+ channels }\end{array}$ & $\begin{array}{l}\text { L-type } \\
\text { Ca2+channels }\end{array}$ & $\begin{array}{l}\text { Voltage-gated K+ } \\
\text { channels }\end{array}$ & $\begin{array}{l}\text { MDR-mediated flux } \\
\text { from tumor cells }\end{array}$ & [1] \\
\hline ACE inhibitors: & Arterial hypertension & $\begin{array}{l}\text { AT II inhibitors, } \\
\text { AT II receptor } \\
\text { blockers }\end{array}$ & $\begin{array}{l}\text { RAS, ATII, VEGF } \\
\text { activation, neoangi- } \\
\text { ogenesis }\end{array}$ & $\begin{array}{l}\text { Prostate, gastric } \\
\text { cancer - marginal } \\
\text { effects }\end{array}$ & [7] \\
\hline $\begin{array}{l}\text { Inotropics } \\
\text { Digitalis art failure - } \\
\text { digoxin }\end{array}$ & $\begin{array}{l}\mathrm{Na}(+) / K(+)-A T P a s e \\
\text { inhibition }\end{array}$ & $\begin{array}{l}\mathrm{Na}(+) / K(+)- \\
\text { ATPase }\end{array}$ & $\begin{array}{l}\text { Death receptors } \\
\text { Glycolysis }\end{array}$ & $\begin{array}{l}\text { Controversial clinical } \\
\text { results, mostly cancer } \\
\text { increase (breast, ovary, } \\
\text { cervix uteri) }\end{array}$ & [7] \\
\hline $\begin{array}{l}\text { RAS Losartan } \\
\text { Captopril }\end{array}$ & $\begin{array}{l}\text { Hypertension } \\
\text { Heart failure }\end{array}$ & $A C E, A T I R$ & ATTR modulation & $\begin{array}{l}\text { General antiangiogenic, } \\
\text { and antimetastatic } \\
\text { effects in vivo }\end{array}$ & [1] \\
\hline $\begin{array}{l}\text { Antianginal } \\
\text { Nitroglycerin }\end{array}$ & Chronic heart disease & $\begin{array}{l}\text { GMP to cGMP } \\
\text { conversion }\end{array}$ & cGMP generation & $\begin{array}{l}\text { Increased response } \\
\text { of cancer cells to } \\
\text { cytostatic therapy } \\
\text { in vitro and in vivo }\end{array}$ & [1] \\
\hline $\begin{array}{l}\text { Alphal-adrenocep- } \\
\text { tor antagonists } \\
\text { Terazosin } \\
\text { Alfuzosin, Prazosin }\end{array}$ & Hypertension, BPH & AIR & $\begin{array}{l}A 1 R, \text { EGF receptor } \\
\text { affected }\end{array}$ & Solid tumor cell lines & [1] \\
\hline $\begin{array}{l}\text { Blockers of } \\
\boldsymbol{\beta} \text {-Adrenoreceptors } \\
\text { Propranolol etc. }\end{array}$ & $\begin{array}{l}\text { Asthma etc., } \\
\text { stress-associated } \\
\text { disorders }\end{array}$ & $\beta$-Adrenoreceptors & $\begin{array}{l}\beta \text {-AR: cAMP-PKA } \\
\text { activation }\end{array}$ & $\begin{array}{l}\text { Breast, ovarian, } \\
\text { melanoma }\end{array}$ & [7] \\
\hline $\begin{array}{l}\text { Antiepileptic } \\
\text { Valproic acid }\end{array}$ & Epilepsia & GABA ergic & $\begin{array}{l}\text { Blocking NMDA Na+ } \\
\text { channels }\end{array}$ & Class I-II HDACs PPAR $\gamma$ & {$[1,4]$} \\
\hline $\begin{array}{l}\text { Antidiabetics } \\
\text { Glitazones } \\
\text { Metformin }\end{array}$ & Diabetes mellitus & $\begin{array}{l}\text { PPAR } \gamma \\
\text { AMPK } \\
\text { (LKBl-dependent) }\end{array}$ & $\begin{array}{l}\text { PPAR } \gamma \\
\text { AMPK }\end{array}$ & Solid tumor cells & {$[1,5]$} \\
\hline $\begin{array}{l}\text { Cholesterol } \\
\text { lowering agents } \\
\text { Statins }\end{array}$ & Cholesterolemia & HMGC & $\begin{array}{l}\text { HMGC, downstream } \\
\text { GGPP and farnesyl } \\
\text { PP inhibition }\end{array}$ & $\begin{array}{l}\text { Apoptosis promotion } \\
\text { Controversial data on } \\
\text { lower cancer rates }\end{array}$ & [7] \\
\hline Statins & Atherosclerosis & HMGC & $\begin{array}{l}\text { Multiple points } \\
\text { (Pisanti) in tumor } \\
\text { cells and immune } \\
\text { cells }\end{array}$ & $\begin{array}{l}\text { Inhibition of prolife- } \\
\text { ration, apoptosis, } \\
\text { anti-inflammatory ac- } \\
\text { tion: lung and stomach } \\
\text { cancer, CLL }\end{array}$ & [8] \\
\hline $\begin{array}{l}\text { Antiinflammatory } \\
\text { Aspirin }\end{array}$ & Inflammation & $\begin{array}{l}\text { COX2 - TXA2 } \\
\text { suppression }\end{array}$ & $\begin{array}{l}\text { COX1-2-PGE2 } \\
\text { suppression }\end{array}$ & & [7] \\
\hline
\end{tabular}


REVIEW ARTICLES

\begin{tabular}{|c|c|c|c|c|c|}
\hline Agent & Primary indication & $\begin{array}{l}\text { On-target- } \\
\text { TARGET Primary } \\
\text { effects } \\
\end{array}$ & $\begin{array}{l}\text { On target } \\
\text { antitumor effects }\end{array}$ & $\begin{array}{l}\text { Biological antitumor } \\
\text { effects }\end{array}$ & Reference \\
\hline $\begin{array}{l}\text { Antimalarial drugs } \\
\text { Chloroquine }\end{array}$ & Malaria & Lysosomas & Lysosomas & Autophagia & {$[1,9,10]$} \\
\hline Quinacrine & Antimalarial & $\begin{array}{l}\text { Topoisomerase T, } \\
\text { NFkB inhibition }\end{array}$ & $\begin{array}{l}\text { DNA topoisomerase, } \\
\text { helicase }\end{array}$ & $\begin{array}{l}\text { Solid and other cell } \\
\text { lines suppressed }\end{array}$ & {$[4,11]$} \\
\hline Fluoroquinolones & Antibacterials & $\begin{array}{l}\text { Topoisomerase } \\
\text { Il inhibitors }\end{array}$ & $\begin{array}{l}\text { Bacterial and } \\
\text { eukaryotic } \\
\text { topoisomerases }\end{array}$ & $\begin{array}{l}\text { Suppresion of proin- } \\
\text { flammatory cytokines } \\
\text { and chemokine produc- } \\
\text { tion }\end{array}$ & [12] \\
\hline $\begin{array}{l}\text { Antibacterials } \\
\text { Doxycycline }\end{array}$ & Infections & MMP3 & $\begin{array}{l}\text { MMP 2,3,9, inhib. } \\
\text { cell proliferation, } \\
\text { neoangiogenesis }\end{array}$ & Melanoma (exp.) & [13] \\
\hline Tetracyclines & $\begin{array}{l}\text { Broad -spectrum } \\
\text { anti-bacterial drug }\end{array}$ & $\begin{array}{l}\text { Binding the } 305 \\
\text { bacterial subunit }\end{array}$ & $\begin{array}{l}\text { Binding } 285 \text { ribo- } \\
\text { somal subunit in } \\
\text { eukaryotic mito- } \\
\text { chondria }\end{array}$ & $\begin{array}{l}\text { Suppression of protein } \\
\text { synthesis in normal and } \\
\text { malignant cells }\end{array}$ & [14] \\
\hline Tigecycline & $\begin{array}{l}\text { Broad -spectrum } \\
\text { anti-infectious agents }\end{array}$ & $\begin{array}{l}\text { Binding the } 305 \\
\text { subunit of bacterial } \\
\text { ribosomes }\end{array}$ & $\begin{array}{l}\text { Binding } 285 \text { ribo- } \\
\text { somal subunit in } \\
\text { eukaryotic mito- } \\
\text { chondria }\end{array}$ & $\begin{array}{l}\text { Suppression of ALL } \\
\text { cells, primary lympho- } \\
\text { cytes and CD34 progen- } \\
\text { itors. In vitro inhibition } \\
\text { of solid tumors }\end{array}$ & {$[15,16]$} \\
\hline Azithromycin & $\begin{array}{l}\text { Broad-spectrum effects } \\
\text { (erythromycin group) }\end{array}$ & $\begin{array}{l}505 \text { bacterial ribo- } \\
\text { some inhibition }\end{array}$ & $\begin{array}{l}\text { Suppression of } \\
395 \text { mitochondrial } \\
\text { ribosomes }\end{array}$ & $\begin{array}{l}\text { In vitro inhibition of } \\
\text { mammosphere formed } \\
\text { by MCF7, T47D and oth- } \\
\text { er solid tumor cells }\end{array}$ & [16] \\
\hline Azithromycin & Infections & $\begin{array}{l}\text { Protein synthesis } \\
\text { suppression }\end{array}$ & $\begin{array}{l}\text { Antileukemic } \\
\text { effects, antiinflam- } \\
\text { matory effects } \\
\text { in vivo }\end{array}$ & $\begin{array}{l}\text { Decreased rates of } \\
\text { relapse in patients } \\
\text { treated with azithromy- } \\
\text { cin for CGVHD }\end{array}$ & [17] \\
\hline Clarithromycin & Broad-spectrum effects & $\begin{array}{l}\text { Protein synthesis } \\
\text { suppression }\end{array}$ & $\begin{array}{l}\text { Apoptosis of lym- } \\
\text { phoma cells by TNF/ } \\
\text { caspase pathway }\end{array}$ & $\begin{array}{l}\text { Effective in MM and } \\
\text { WMgu }\end{array}$ & [18] \\
\hline $\begin{array}{l}\text { Antiviral drugs: } \\
\text { Efavirenz }\end{array}$ & HIV infection & $\begin{array}{l}\text { Reverse } \\
\text { transcriptase } \\
\text { inhibition } \\
\end{array}$ & $\begin{array}{l}\text { 0xidative stress, } \\
\text { p53 activation, } \\
\text { apoptosis induction }\end{array}$ & Leukemia cell lines & [19] \\
\hline Amantadine & $\begin{array}{l}\text { Anti-viral and } \\
\text { anti-Parkinson drug }\end{array}$ & C/EBPa expression & $\begin{array}{l}\text { Vitamin D receptor } \\
\text { induction. Monocyte } \\
\text { differentiation }\end{array}$ & $\begin{array}{l}\text { HL60, U937, myeloid } \\
\text { leukemia cell lines } \\
\text { (combined with subop- } \\
\text { timal ATRA) }\end{array}$ & [20] \\
\hline Itroconazole & Fungal invasions & $\begin{array}{l}\text { Antimetabolic } \\
\text { effects Autophagic } \\
\text { growth arrest }\end{array}$ & $\begin{array}{l}\text { Neoangiogenesis } \\
\text { inhibition }\end{array}$ & & [21] \\
\hline Salinomycin & Coccidiosis & $\begin{array}{l}\text { lonophor }(\mathrm{K}+, \mathrm{Ca}++ \\
\text { transfer into the } \\
\text { cells) }\end{array}$ & $\begin{array}{l}\text { Activates apoptosis } \\
\text { in a p53/ } \\
\text { Caspase-indepen- } \\
\text { dent manner }\end{array}$ & $\begin{array}{l}\text { Human and murine AML } \\
\text { and } M M L \text { cell lines }\end{array}$ & [22] \\
\hline $\begin{array}{l}\text { Antihelminth } \\
\text { Niclosamide }\end{array}$ & Helminthoses & $\begin{array}{l}\text { GSH synthetase } \\
\text { (GS) }\end{array}$ & $\begin{array}{l}\text { ROS induction, MDR } \\
\text { suppression, nuclear } \\
\text { factor of activated } \\
\text { T-cells (NFAT) } \\
\text { decreased }\end{array}$ & $\begin{array}{l}\text { Leukemia, myeloma and } \\
\text { CRC cell lines inhibition } \\
\text { of different transcrip- } \\
\text { tion factors }\end{array}$ & {$[23,24]$} \\
\hline
\end{tabular}




\section{Drug repositioning for leukemia treatment}

\section{Metformin}

This well-known anti-diabetic drug activates the AMF-regulated protein kinase pathway dependent on the tumor suppressor LKB1. The LKB1/AMPK signaling may be suppressed by ERK which is activated in a half of acute myeloid leukemia (AML) cases with appropriate mutations, e.g., FLT3-ITD mutation. These cases may be susceptible for metformin and the treatment efficiency may be increased in combination with sorafenib or other novel drugs $[25,26]$.

\section{Chloroquines}

Pre-clinical studies of the last decade have repeatedly confirmed distinct anticancer effects of well-known antimalarial drug chloroquine and its derivatives. In particular, chloroquine and hydroxychloroquine have relatively well-characterized toxicity profiles. Previously published review articles provide an excellent overview on diversity of chloroquine effects on cancer cells, both in the cell culture as well as on human tumors grafted into mice; and suggest incorporation of hydroxychloroquine in prospective combination schemes for clinical studies [9]. The authors discuss some common features in cancer cells that could be targeted by quinacrine and its derivatives, aiming for potential pharmaceutical intervention in oncology.

A recent work by Eriksson et al. [11] dealt with more specific quinacrine effects upon malignant blood cells. The authors have earlier selected quinacrine as the most plausible compound for its antileukemic effects, and tested this drug in vitro in combination with some common cytostatic agents (daunorubicin, cytarabine, azacitidine, etc.). Acute myeloid leukemia (AML) cell lines were cultured as a target population, then tested for cytotoxicity by fluorometric microculture. In most in vitro systems, the workers have shown distinct synergism between quinacrine and cytarabine, or azacitidine added to these cell cultures. Moreover, the in vivo usage of quinacrine (100 mg/kg, six injections for two weeks) in SCID mice bearing human AML cells caused a significant decrease in circulating blast cells and increased the median survival time of the animals. Hence, further studies may offer an "old-new", less toxic drug for combined treatment of leukemia.

\section{Fluoroquinolones}

Quinolone-based antibiotics, especially, fluoroquinolones are used over decades to manage different bacterial and protozoal infections. Their microbicidal action is caused by inhibition of the ligase domain of the type II DNA topoisomerase, thus releasing endonuclease activities and irreversible DNA decay in the target cells, as reviewed by Idowu and Schweizer [12]. Such a universal cytotoxic effect presumes possible applications of fluoroquinolones for cancer treatment. These studies, however, are still in progress and should be substantiated in pre-clinical trials.

\section{Tetracycline, and its derivatives}

This class of antibacterials is known since 1948. Tetracyclines are widely used in medicine and agriculture to combat broad spectrum of bacteria [14]. Despite high proportion of tetracyclin-resistant microorganisms (due to powerful drug efflux), a new generation of these drugs was developed later on (e.g., Doxycycline, Tigecycline) which are now administered for empiric treatment, e.g., in immunocompromised patients following severe cytostatic treatment and bone marrow transplantation. Interestingly, doxorubicin, a popular anticancer antibiotic belongs to the same family of bioactive compounds.

All the tetracyclines inhibit protein assembly in Gram(+) and Gram(-) microbes by preventing the aminoacyl-tRNA binding to the acceptor sites at the ribosomes. Meanwhile, tetracyclines were also tested for treatment of a number of inflammatory diseases, due to their inhibition of matrix metalloproteinases, antiapoptotic, antioxidative, and antiinflammatory effects in humans [14].

Hence, the major antimicrobial effect of tetracyclines is due to their protein-inhibiting actions in bacteria. Moreover, they possess antiproliferative and pro-apoptotic effects in mammalian cancer cells, by suppressing mitochondrial ribosomes and energy metabolism [16]. More recently, they are also considered potential anticancer drugs. E.g., Tigecycline a structural homologue of tetracycline, being a potent glycylcycline antibiotic, is mostly used as a broad-spectrum drug against gram-positive and gram-negative pathogens. It reversibly binds the $30 \mathrm{~S}$ subunit of the bacterial ribosomes, being also an inhibitor of mitochondrial biogenesis [27].

Ten malignant tumor cell lines of different origin were tested in vitro with tigecycline and doxycycline (another tetracycline derivative), showing. Tigecycline has shown its ability to inhibit the MCF7 and T47D spheroid cell growth, at the concentrations from $10 \mu \mathrm{M}$ to $50 \mu \mathrm{M}$ [16]. Moreover, tigecycline was previously shown to kill human AML differentiated blasts as well as leukemic stem cells in vitro and in vivo by blocking mitochondrial protein synthesis [28].

Another work concerned in vitro cytostatic effects of tigecycline on the acute lymphoblastic leukemia (ALL) showing decreased survival and suppression of clonogenic growth in malignant cell cultures [29]. Toxic effects upon normal hematopoietic cells were less pronounced. Pharmacokinetics and potential antitumor effects make this drug a promising option when sensitizing ALL cells for chemotherapy [30].

In particular, tigecycline was studied in the Phase 1 dose-escalation study of tigecycline administered intravenously daily 5 of 7 days for 2 weeks to patients with AML. A total of 27 adult patients with relapsed and refractory AML were enrolled [27]. The authors have shown relative safety and assessed maximal tolerable doses for the drug infused into the patients with relapsed/refractory AML, however, with no evident anticancer effects revealed.

Moreover, some small clinical trials with doxycycline were performed over last years in cancer clinics (primarily aiming for infection therapy, but not cancer treatment) showing some antitumor effects in cancer patients as reviewed by Lamb et al. [16]. Initial positive results of doxycycline trials obtained in advanced or treatment-resistant cases of B-cell lymphoma [30]. This clinical effect was not, however, confirmed in more extensive studies. 


\section{Erythromycin and other macrolides}

These antibacterials may also inhibit various microflora by suppressing ribosome functions. Similarly, they can inhibit mitochondrial ribosomes in eukaryotic cells, as shown in several cancer cell lines [16]. Azithromycin is an improved erythromycin derivative which is widely used in post-transplant patients, being more slowly eliminated than erythromycin. Its anti-infectious effect is exploited for prevention of bacterial complications in chronic infectious conditions, e.g., at later terms post-HSCT.

Surprisingly, a probable antitumor effect of azithromycin was revealed in a study by Shamoun et al. [17] published as a short abstract, where a long-term drug administration (14 days) aimed to ameliorate chronic graft-versus-graft disease (GvHD) was accompanied by decreased rates of relapse and improved survivals in a combined group of with acute leukemia, MDS, malignant lymphomas, and chronic leukemia patients.

Clarithromycin (6-O-methyl erythromycin) is also a widely used semi-synthetic macrolide drug which also has previously shown a sufficient anticancer activity against some experimental tumors [31] when used after a course of cancer chemotherapy in mice.

A recent review by van Nuffel et al. [18] has summarized numerous data obtained in human studies showing complementary effects of clarithromycin as an antibacterial drug in combined treatment of multiple myeloma, CML and other blood malignancies, especially MALT lymphomas and Hodgkin's disease studied over last 2 decades. Their general impression is that the effects of Clarithromycin may be also due to antibacterial action of the drug, thus requiring a search for tumor-targeted effects in these conditions. Clarithromycin significantly enhanced effect of cytostatic treatment by increasing natural killer cell activity and CD8+ T cell cytotoxicity, thus causing recovery from immunosuppression caused by the chemotherapy.

\section{Studies on GvHD prevention}

Distinct positive effects of azithromycin were shown in murine model of experimental GVHD were reported by a Japanese group [32]. Azithromycin was administered per os to recipient $\mathrm{BALB} / \mathrm{c}$ mice during $\mathrm{H}-2$ incompatible $\mathrm{BMT}$. The treatment was performed from day -2 to day +2 . As a result, the drug-treated animals exhibited significant suppression of lethal GVHD without sufficient inhibition of donor cell engraftment. Azithromycin administration was associated with mice $70 \%$ survival of transplanted animals versus death of all mice in control group. Accordingly, the typical GvHD lesions of intestinal and liver epithelium were only minimally expressed in AZM-treated animals. The authors suggest inhibition of recipient DCs as a possible cause of GVHD suppression.

Similar results were obtained by Radhakrishnan et al. [33] in lethally irradiated B6D2F1 mice in whom acute GVHD and noninfectious lung injury were induced by injection of bone marrow and spleen cells from allogeneic C57BL/6 mice. In experimental animals, azithromycin was given for a long time orally from day +14 until 6 or 14 weeks after transplantation. Generally, Azithromycin treatment resulted in improved survival and decreased lung injury, as shown by respiratory tests, and improved GvHD-associated injury of intestines and liver, depending, however, on the schedule of drug gavage.

A small clinical study with azithromycin for GVHD prophylaxis has yielded disappointing results in a randomized, placebo-controlled trial performed by Iranian group [34]. 96 patients with acute leukemia were subjected to HSCT from full-matched donors. All the patients received highdose chemotherapy, standard immunosuppressive regimens. Azithromycin was administered $500 \mathrm{mg}$ daily in 48 cases from day -6 to +12 posttransplant, and placebo was given in other 48 cases. As a result, incidence of acute GvHD grade III-IV and chronic graft-versus-host disease did not significantly differ between the two groups. Meanwhile, oral mucositis occurred in significantly lower number of patients treated with azithromycin.

\section{Niclosamide}

Niclosamide as an approved anthelmintic agent potential anticancer agent by various high-throughput screening campaigns [24]. Niclosamide not only inhibits the Wnt/ $\beta$-catenin, mTORC1, STAT3, NF- $\kappa$ B and Notch signaling pathways, but also targets mitochondria in cancer cells. Therefore, some in vitro screening studies have shown its anticancer activity. In the study by Hamdoun et al. [23], niclosamide showed distinct suppressive effects upon cancer cell lines. Worth of note, it revealed higher activity against leukemia cell lines CCRF-CEM, CEM/ADR5000, and RPMI-8226 compared to the solid tumor cell lines. Cytocidal action of niclosamide may be associated with increase in reactive oxygen species and glutathione (GSH) in malignant cells, thus suggesting GSH synthetase (GS) as a target for niclosamide.

\section{Salinomycin}

Salinomycin is an ionophore successfully used in the patients with coccidiosis seems also to express anti-leukemic effects [22]. AML and MLLr cell lines, primary cells and patient samples were sensitive to submicromolar salinomycin. Interestingly, colony formation of normal hematopoietic cells was unaffected by salinomycin, thus promising safer usage of this drug in further clinical trials.

\section{Antifungal drugs}

Itraconazole, a common anti-fungal agent, has demonstrated potential anticancer activity, including P-glycoprotein-mediated resistance by modulating the Hedgehog signaling pathways which are a target of rapamycin and Wnt/ $\beta$-catenin in cancer cells. Angiogiogenesis suppression is another known effect of itroconazole in the cancer microenvironment [35]. Small clinical trials suggested the clinical benefits of itraconazole monotherapy in different solid tumors [21].

\section{Possible clinical effects of antibacterials due to posttransplant changes of gut microbiota}

Firstly, antibacterial antibiotics, especially, for oral use, are prone for suppression of gut microbiota. E.g., Shono et al [36] have shown that some widely used antibacterials, e.g., piperacillin/tazobactam or imipenem/cilastatin are followed 
by higher GVHD-related death at 5 years, due to gut microflora imbalance. Therefore, an extending viewpoint suggests damaging effects of antibacterials upon normal microbiota, thus being potentially harmful to immune reconstitution after HSCT and affect clinical outcomes in the patients [37].

\section{Conclusion}

At the present time, there is a wide list of repurposed drugs potentially applicable in cancer therapy. Of course, most of these "old" drugs are tested in vitro or in pre-clinical animal models. Hundreds of the candidate compounds are subjected to screening in susceptible malignant cell lines, then treated by means of bioinformatics techniques. Only some drugs are proposed for further pre-clinical and clinical studies, thus presentibg some hopes for successful introduction of these medications within combined schedules of cancer chemotherapy.

Introduction of the "old-new" anticancer drugs should inevitably pass the step of cell culture testing, animal experiments and clinical trials, in order to confirm antitumor activities for different malignancies. Their testing for the therapy of oncohematological disorders has made a sufficient progress over last years, first of all, by in vitro screening studies of leukemic cell lines performed worldwide. The searched additional effects upon biological pathways in malignant cells may be discerned by means of functional genomics and "big data" mining technologies, thus providing comprehensive information concerning the drug targets [6]. The authors propose a novel functional concept of pharmacology implying artificial intelligence techniques for mining and knowledge discovery in "big data" providing comprehensive information about the drugs associated with activation or suppression of appropriate biological pathways. By this approach, the workers have designed indexes of optimal drugs for treatment of hypertension, analgesia, and candidate drugs for treatment of chronic lymphocytic leukemia. Likewise, the strategy provides successful selection of candidate drugs for repurposing tasks.

\section{Conflict of interest}

No conflicts of interest are reported.

\section{References}

1. Dueñas-González A, García-López P, Herrera LA, Medina-Franco JL, González-Fierro A, CandelariaM. The prince and the pauper. A tale of anticancer targeted agents. Molecular Cancer 2008; 7:82 doi:10.1186/1476-4598-7-82.

2. Sukhai MA, Spagnuolo PA, Weir S, Kasper J, Patton L, Schimmer AD. New sources of drugs for hematologic malignancies. Blood. 2011;117(25):6747-6755.

3. Drug Repurposing Portal http://drugrepurposingportal. com/repurposed-drug-database.php

4. Andresen V, Gjertsen BT. Drug repurposing for the treatment of acute myeloid leukemia. Front. Med. 2017. 4:211. doi: 10.3389/fmed.2017.00211.
5. Shah RR, Stonier PD. Repurposing old drugs in oncology: Opportunities with clinical and regulatory challenges ahead. J Clin Pharm Ther. 2019;44(1):6-22. doi: 10.1111/ jcpt.12759.

6. Lötsch J, Ultsch A. Process pharmacology: a pharmacological data science approach to drug development and therapy. CPT Pharmacometrics Syst Pharmacol. 2016 Apr;5(4):192-200. doi: 10.1002/psp4.12072.

7. Ishida J, Konishi M, Ebner N, Springer J. Repurposing of approved cardiovascular drugs. J Transl Med. 2016;14:269. doi: 10.1186/s12967-016-1031-5.

8. Pisanti S, Picardi P, Ciaglia E, D'Alessandro A, Bifulco $M$. Novel prospects of statins as therapeutic agents in cancer. Pharmacol Res. 2014;88:84-98. doi: 10.1016/j. phrs.2014.06.013.

9. Vlahopoulos S, Critselis E, Voutsas IF, Perez SA, Moschovi M, Baxevanis CN, Chrousos GP. New use for old drugs? Prospective targets of chloroquines in cancer therapy. Curr Drug Targets. 2014;15(9):843-51.

10. Plantone D, Koudriavtseva T. Current and future use of chloroquine and hydroxychloroquine in infectious, immune, neoplastic, and neurological diseases: A mini-review. Clin Drug Investig. 2018;38(8):653-671.

11. Eriksson A, Chantzi E, Fryknäs M, Gullbo J, Nygren P, Gustafsson M, Höglund M, Larsson R. Towards repositioning of quinacrine for treatment of acute myeloid leukemia - Promising synergies and in vivo effects. Leuk Res. 2017;63:41-46. doi: 10.1016/j.leukres.2017.10.012.

12. Idowu T, Schweizer F. Ubiquitous nature of fluoroquinolones: the oscillation between antibacterial and anticancer activities. Antibiotics. 2017; 6, 26; doi:10.3390/antibiotics6040026.

13. Shehwaro N, Langlois AL, Gueutin V, Gauthier M, Casenave M, Izzedine H. Doxycycline or how to create new with the old? Therapie. 2014;69(2):129-141 (In French). doi: $10.2515 /$ therapie/2013069.

14. Fuoco D. Classification framework and chemical biology of tetracycline-structure-based drugs. Antibiotics 2012, 1:1-13.

15. Fu X, Liu W, Huang Q, Wang Y, Li H, Xiong Y. Targeting mitochondrial respiration selectively sensitizes pediatric acute lymphoblastic leukemia cell lines and patient samples to standard chemotherapy. Am J Cancer Res. 2017;7(12):2395-2405.

16. Lamb R, Ozsvari B, Lisanti CL, Tanowitz HB, Howell A, Martinez-Outschoorn UE, Sotgia F, Lisanti MP. Antibiotics that target mitochondria effectively eradicate cancer stem cells, across multiple tumor types: Treating cancer like an infectious disease. Oncotarget; 2015; 6(7): 4569-4584.

17. Shamoun M, Braun Th, Magenau JM, Choi SW, Reddy P, Pawarode A, Riwes MM, Kitko CL, Anand S, Ghosh M, Lugt MW, Bonifant C, Abusin G, Parkin B, Peltier D, Yanik GA.The effect of azithromycin on relapse in patients with moderate-severe chronic graft versus host disease (CGVHD). Biol Blood Marrow Transplant. 2019; 25 (Abstracts):S26-S27. 
18. Van Nuffel ANT, Sukhatme W, Pantziarka P, Meheus L, Sukhatme VP, Bouche G. Repurposing Drugs in Oncology (ReDO)-clarithromycin as an anti-cancer agent. ecancer 2015, 9:513 DOI: 10.3332/ecancer.2015.513

19. Brüning A, Jückstock J, Kost B, Tsikouras P, Weissenbacher T, Mahner S, Mylonas I. Induction of DNA damage and apoptosis in human leukemia cells by efavirenz. Oncol Rep. 2017 ;37(1):617-621. doi: 10.3892/or.2016.5243. Epub 2016 Nov 15.

20. Manzotti G, Parenti S, Ferrari-Amorotti G, Soliera AR, Cattelani S, Montanari M, Cavalli D, Ertel A, Grande A, Calabretta B. Monocyte-macrophage differentiation of acute myeloid leukemia cell lines by small molecules identified through interrogation of the Connectivity Map database. Cell Cycle. 2015; 14(16): 2578-2589.

21. Pantziarka P, Sukhatme V, Bouche G, Meheus L, Sukhatme VP. Repurposing Drugs in Oncology (ReDO)itraconazole as an anti-cancer agent. Ecancermedicalscience. 2015;9:521. doi: 10.3332/ecancer.2015.521.

22. Roulston GDR, Burt CL, Kettyle LMJ, Matchett KB, Keenan HL, Mulgrew NM, RamseyJM, Dougan C, McKiernan J, Grishagin IV, Mills KI, Thompson A. Low-dose salinomycin induces anti-leukemic responses in AML and MLL. Oncotarget. 2016 7(45): 73448-73461. doi: 10.18632/oncotarget.11866.

23. Hamdoun S, Jung P, Efferth T. Drug repurposing of the anthelmintic niclosamide to treat multidrug-resistant leukemia. Front Pharmacol. 2017;8:110. doi: 10.3389/ fphar.2017.00110.

24. Li Y, Li PK, Roberts MJ, Arend RC, Samant RS, Buchsbaum DJ. Multi-targeted therapy of cancer by niclosamide: A new application for an old drug. Cancer Lett. 2014;349(1):814. doi: 10.1016/j.canlet.2014.04.003.

25. Wang F, Liu Z, Zeng J, Zhu H, Li J, Cheng X, et al. Metformin synergistically sensitizes FLT3-ITD-positive acute myeloid leukemia to sorafenib by promoting mTOR-mediated apoptosis and autophagy. Leuk Res. 2015; 39:1421-1427. doi:10.1016/j.leukres.2015.09.016.

26. Sabnis HS, Bradley HL, Tripathi S, Yu WM, Tse W, Qu $\mathrm{CK}$, et al. Synergistic cell death in FLT3-ITD positive acute myeloid leukemia by combined treatment with metformin and 6-benzylthioinosine. Leuk Res. 2016; 50:132-140. oi:10.1016/j.leukres.2016.10.004.

27. Reed GA, Schiller GJ, Kambhampati S Tallman MS, Douer Dan, Minden MD, Yee KW, Gupta V, Brandwein J, Jitkova Yu, Gronda M, Hurren R, Shamas-Din A, Schuh AC, Skrtic M, Sriskanthadevan S, Jhas B, Gebbia M, Wang X, Wang Z, et al. 2011. Inhibition of mitochondrial translation as a therapeutic strategy for human acute myeloid leukemia. Cancer Cell; 20:674-688.

28. Skrtić M, Sriskanthadevan S, Jhas B, Gebbia M, Wang X, Wang Z, Hurren R, Jitkova Y, Gronda M, Maclean N, Lai CK, Eberhard Y, Bartoszko J, Spagnuolo P, Rutledge AC, Datti A, Ketela T, Moffat J, Robinson BH, Cameron JH, Wrana J, Eaves CJ, Minden MD, Wang JC, Dick JE, Humphries K, Nislow C, Giaever G, Schimmer AD. Inhibition of mito- chondrial translation as a therapeutic strategy for human acute myeloid leukemia. Cancer Cell. 2011; 20(5):674-88. doi: 10.1016/j.ccr.2011.10.015.

29. Schimmer AD. A phase 1 study of intravenous infusions of tigecycline in patients with acute myeloid leukemia. Cancer Medicine, 2016; 5(11):3031-3040.

30. Ferreri AJ, Ponzoni M, Guidoboni M, Resti AG, Politi LS, Cortelazzo S, Demeter J, Zallio F, Palmas A, Muti G, Dognini GP, Pasini E, Lettini AA, Sacchetti F, De Conciliis C, Doglioni C, Dolcetti R. Bacteria-eradicating therapy with doxycycline in ocular adnexal MALT lymphoma: a multicenter prospective trial. J Natl Cancer Inst. 2006; 98(19): 1375-1382.

31. Sassa K, Mizushima Y, Fujishita T, Oosaki R, Kobayashi M. Therapeutic effect of clarithromycin on a transplanted tumor in rats. Antimicrob Agents Chemother. 1999; 43(1):67-72.

32. Iwamoto S., Azuma E., Kumamoto T., Hirayama M., Yoshida T., Ito M., Amano K., Ido M., Komada Y. Efficacy of azithromycin in preventing lethal graft-versus-host disease. Clinical and Experimental Immunology, 2012;171:338-345.

33. Radhakrishnan SV, Palaniyandi S, Mueller G, Miklos S, Hager M, Spacenko E, Karlsson FG, Huber E, Kittan NA, Hildebrandt GC. Preventive azithromycin treatment reduces noninfectious lung injury and acute graft-versushost disease in a murine model of allogeneic hematopoietic cell transplantation. Biol Blood Marrow Transplant. 2015; 21:30-38.

34. Barkhordar M, Mohammadi M, Hadjibabaie M, Ghavamzadeh A. SupplAzithromycin for prevention of graftversus-host disease: A randomized placebo-controlled trial. Int J Hematol Oncol Stem Cell Res. 2018;12(2):77-83.

35. Tsubamoto H, Ueda T, Inoue K, Sakata K, Shibahara $\mathrm{H}$, Sonoda T. Repurposing itraconazole as an anticancer agent. Oncol Lett. 2017;14(2):1240-1246. doi: 10.3892/ ol.2017.6325.

36. Shono Y, Docampo MD, Peled JU, Perobelli SM, Velardi E, Tsai JJ, Slingerland AE, Smith OM, Young LF, Gupta J, Lieberman SR, Jay HV, Ahr KF, Porosnicu Rodriguez KA, Xu K, Calarfiore M, Poeck H, Caballero S, Devlin SM, Rapaport F, Dudakov JA, Hanash AM, Gyurkocza B, Murphy GF, Gomes C, Liu C, Moss EL, Falconer SB, Bhatt AS, Taur Y, Pamer EG, van den Brink MRM, Jenq RR. Increased GVHD-related mortality with broad-spectrum antibiotic use after allogeneic hematopoietic stem cell transplantation in human patients and mice. Sci Transl Med. 2016 May 18; 8(339): 339ra71.

37. Goloshchapov OV, Kucher MA, Chukhlovin AB. Gut microbiome in hematopoietic stem cell transplantation: patient and treatment-related factors. Cell Ther Transpant. 2018; 7(4): 16-28. 


\title{
«Переназначение» лекарственных препаратов в лечении лейкозов и при трансплантации гемопоэтических стволовых клеток
}

\author{
Алексей Б. Чухловин \\ НИИ детской онкологии, гематологии и трансплантологии им. Р. М. Горбачевой, Первый Санкт-Петербургский \\ государственный медицинский университет им. И. П. Павлова, Санкт-Петербург, Россия
}

\section{Резюме}

В течение последнего десятилетия появился целый ряд исследований, касающихся возможного применения «старых» медицинских препаратов в качестве дополнительных средств для лечения злокачественных новообразований. Есть следующие главные причины подобного расширения показаний для этих препаратов: (1) ограниченная эффективность и высокая стоимость новых таргетных ингибиторов онкогенных белков, или моноклональных антител для терапии; (2) выявление новых молекулярных мишеней для ряда препаратов, ранее внедренных по другим показаниям; (3) существенное снижение затрат на разработку новых средств терапии, осуществляемой «старыми» препаратами. Перечень таких «перенацеленных» препаратов сейчас включает десятки лекарств, которые часто используются, в частности, для лечения сердечно-сосудистых заболеваний, сахарного диабета, эпилепсии, различных воспалительных заболеваний. Данный обзор касается, главным образом, «переназначения» антиинфекционных препаратов, в т.ч. тех, которые используются для профилактики и лечения инфекционных осложнений, возникающих при цитостатической терапии лейкозов и лимфом, в частности тетрациклинов, производных эритромицина, а также фторхинолонов, антивирусных препаратов и др.
Противоопухолевые эффекты этих препаратов-кандидатов для «переназначение» были показаны при скрининге их цитостатических эффектов на линиях лейкозных и других злокачественных клеток. Некоторые исследования проведены на экспериментальных животных-опухоленосителях. Немногие клинические испытания были проведеные в группах пациентов с лейкозами и лимфомами после трансплантации гемопоэтических стволовых клеток (ТГСК), которые показали некоторые позитивные эффекты антибактериальных препаратов в плане профилактики реакции «трансплантат против хозяина» (РТПХ) или увеличения продолжительности жизни пациентов. В этих целях необходимы контролируемые клинические исследования часто применяемых антиинфекционных препаратов.

\section{Ключевые слова}

Антибактериальные препараты, переназначение, противоопухолевые эффекты, терапия лейкозов, трансплантация гемопоэтических стволовых клеток. 